THE EFFECT OF RETURN ON ASSETS, COMPANY SIZE AND FINANCIAL

LEVERAGE ON SMOOTHING MEASURES (EMPIRICAL STUDY ON

STATE-OWNED CONSTRUCTION COMPANIES LISTED IN THE JAKARTA

ISLAMIC INDEX FOR THE 2015-2018 PERIOD)

\title{
THE EFFECT OF RETURN ON ASSETS, COMPANY SIZE AND \\ FINANCIAL LEVERAGE ON SMOOTHING MEASURES (EMPIRICAL STUDY ON STATE-OWNED CONSTRUCTION COMPANIES LISTED IN THE JAKARTA ISLAMIC INDEX FOR THE 2015-2018 PERIOD)
}

\author{
Ari Kristin Prastyoningrum ${ }^{1}$, Dessy Noor Farida ${ }^{2}$, Vanila Hapsari ${ }^{3}$ \\ ${ }^{1}$ Fakultas Ekonomi dan Bisnis Islam, UIN Walisongo Semarang, Indonesia \\ ${ }^{2}$ Fakultas Ekonomi dan Bisnis Islam, UIN Walisongo Semarang, Indonesia \\ ${ }^{3}$ Fakultas Ekonomi dan Bisnis Islam, UIN Walisongo Semarang, Indonesia
}

\begin{abstract}
The Indonesian government announces that Indonesia will have a new National Capital, one of it's aims is to smooth the people's economy. Many companies in the construction sector owned by BUMN have long been listed on the Sharia stock exchange. With the existence of this mega project, the recording of profits of go-public companies as well as government-owned companies will receive special attention related to the recording of profits in several previous periods. However, investors must be observant regarding the possibility of companies taking income smoothing actions, some of which are through Return On Assets, Size of the Company and Financial Leverage.

The object of research is BUMN construction companies listed in the Jakarta Islamic Index (JII) from 2015 to 2018. The samples used 3 companies based on purposive sampling. Hypothesis testing uses multiple linear regression to test the effect of Return On Assets, Size of the Company and Financial Leverage on Income Smoothing actions by calculating Income Smoothing using the Eckel Index, the analysis technique used is linear regression and the hypothesis testing tool is SPSS 16. The results showed that Return On Assets and Size of the Company had no effect on income smoothing. Meanwhile, Financial Leverage affects income smoothing. Keywords: Return On Asset, Size of The Company, Financial Leverage, Income Smoothing.
\end{abstract}

Keywords: Return On Asset, Ukuran Perusahaan, Financial Leverage, Income Smoothing.

\section{INTRODUCTION}

Indonesia is one of the countries that has a dense population. In 2017, the population was recorded at 264,000,000. Along with the growth of Indonesia's population, the Government plans to move the State Capital (IKN) to the North Penajam Paser City, East Kalimantan Province. One of the goals of the IKN line is for the Indonesian economy to grow evenly, not centered on Java Island, while Java Island, especially DKI Jakarta, is already very dense and the economies of other islands are lagging behind. The economy is an important instrument for every country to prosper its people. One of the ways to achieve economic distribution outside Java is that infrastructure must also supported. The state prioritizes the development of public infrastructure because it is in a development that can increase economic growth and public services equitably

*Corresponding author. Email address: ari_kristin@walisongo.ac.id 


\section{AFEBI Islamic Finance and Economic Review (AIFER)}

\section{Vol.3 No.2, December 2018}

in the long run. This prediction is evident from the fact that investment in the infrastructure sector increases every year. The impact of priority infrastructure is to provide accelerated growth for various related industries, but will also provide complexity through increased risk. Infrastructure in this case is through state-owned construction companies that will plan and carry out the construction of the IKN. After it was announced that the IKN would move to North Penajam Paser City in 2024, now the land price in the area has increased dramatically even though the construction of the IKN plan will only begin in 2020 .

Some of these BUMNs include publicly traded companies listed on the Jakarta Islamic Index (JII), namely PT. Waskita Karya (Persero) Tbk, PT. Waskita Beton Precast (Persero) Tbk and PT. Wijaya Karya (Persero) Tbk. The three companies are companies that will contribute to building a new IKN, this project can make share prices soar along with the IKN project agreement. Investors are increasingly interested in investing in the three state-owned construction companies because they have large projects, and of course investors hope to get large dividends as well. Oftentimes investors only look at annual reports in the profit and debt section, but it is likely that the company "makes" its financial statements with the aim of attracting investors by smoothing income. The aim is to prove to outsiders that the company has a low risk, provide relevant information in predicting future earnings, increase business relationship satisfaction, increase positive thinking from external parties regarding company performance. The practice of income smoothing carried out by management is a rational and logical action because there is a reason to reduce the current year's profit and expenses so that the tax payable on the company is smaller. This means that the company does not convey the company's financial condition so that investors only see reports made by management so that they can manipulate. On the other hand, HR. Bukhari stated that

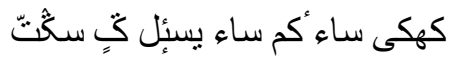

Meaning: "each of you is a leader, and every leader will be held accountable" (Narrated by Bukhari)

In the context of this research, the hadith states that the leader in this case is the one who manages finances and must be accountable to internal and external parties regarding the financial statements of the company one leads.

\section{HYPOTHESIS}

\section{Agency Theory}

Agency theory is a relationship or contract between the owner (principal) and the agent, this is what happens in modern companies. The principal is the individual who invests in a company while an agent is a person who works for the principal and provides information to the principal about how the company is doing. Agency theory assumes that each individual acts in accordance with their own personal interests, so that it can create a conflict of interest between the owner (principal) and the agent. The difference in interests between each party, especially from the manager whose performance is measured based on the profit generated makes the manager try to achieve his desires easily through the manipulation of earnings contained in the financial statements with income smoothing. 


\section{THE EFFECT OF RETURN ON ASSETS, COMPANY SIZE AND FINANCIAL LEVERAGE ON SMOOTHING MEASURES (EMPIRICAL STUDY ON STATE-OWNED CONSTRUCTION COMPANIES LISTED IN THE JAKARTA ISLAMIC INDEX FOR THE 2015-2018 PERIOD)}

\section{Perataan Laba (Income Smoothing)}

Income smoothing is an action to minimize fluctuations in earnings that will be reported in each period. Income smoothing is used to smooth the fluctuations in earnings that occur each period so that the amount of profit generated for each period does not overly fluctuate. So that users of financial reports assess that the company's management performance as seen from the profit shows a definite performance, so that potential investors are sure of the profits that will be generated by a company. Methods often used to distribute profits:

1. Companies now prefer discount and credit policies. At the end of the quarter period, the amount of accounts receivable and sales and profits will appear stable at a certain period position.

2. Smoothing through the timing of transactions or transaction acknowledgments.

Smoothing through allocations for certain periods.

\section{Return On Asset}

Return On Asset is a ratio used to determine the ratio of net profit after tax to total company assets. The company's ability to generate profits on the basis of its assets shows the value of ROA. The variable Return On Asset (ROA) is measured by earning after tax (the ratio between profit) after tax and total assets, the calculation of ROA uses a ratio scale.

$$
\text { Return On Asset }(\mathrm{ROA})=\frac{\text { Earning After Tax } \times 100 \%}{\text { Total Assets }}
$$

\section{Company Size}

The size of the company or firm size is the size or size of the company which is assessed in terms of total assets consisting of sales, total assets and others.

\section{Financial Leverage}

Leverage can occur when a company in its operations uses assets and sources of funds. The use of assets that cause fixed expenses is called operating leverage, while the use of funds with fixed expenses is called financial leverage.

\section{Definition of Profit}

Accounting profit has characteristics, including:

a. Accounting profit is based on actual transactions primarily those that arise from the sale of goods or services.

b. Accounting profit is based on the periodization postulate and refers to the company's performance in a certain period.

c. Accounting profit is a measurement of expenses in the form of historical costs.

\section{Purpose of Profit Reporting}

Indirectly, earnings information can be used to fulfill various purposes including:

a. The basis for making business decisions by the company management

b. Management achievement measure. 


\section{AFEBI Islamic Finance and Economic Review (AIFER)}

\section{Vol.3 No.2, December 2018}

c. The basis for determining the amount of corporate tax.

d. Determine the dividends to be distributed.

\section{Islamic View of Profit}

In the National Sharia Council Fatwa No. 87 / DSN-MUI / XII / 2012 allows income smoothing by taking into account:

a. Decree of AAOIFI (Accounting and Auditing Organization for Islamic Financial Institutions) in Syari's Syari, number: 12 (number 3/1/5/14) which states if:

"Based on the company's articles of association or the decision of the shareholders, the company may hold company profits without being shared, or set aside a certain amount of profit periodically to strengthen the company's performance (solvency reserve) or form a special reserve to mitigate the risk of capital loss (investment risk reserve). or to maintain the stability of the profit sharing (profit equalization reserve) "

b. Opinion of Wahbah al-Zuhail in Kitabal-Fiqhal-Islami wa Adillatuhu (Juz V, p. 3939):

"The Hanafiah Ulama is exaggerating to make a condition that one of the parties with the contract receives a certain amount of dinar which is known in terms of business profits exceeding a certain value. This requirement is considered valid and does not affect the validity of the mudharabah contract, because it does not lead to unclear profit (share). "

Decided that:

The income smoothing method is an arrangement for the recognition and reporting of profit or income from time to time by retaining a portion of the income in one period and diverted it in another period with the aim of reducing excessive fluctuations in profit sharing between Islamic Financial Institutions ( LKS) and customers who deposit funds (Third Party Funds or DPK)

\section{Theoritical framework :}

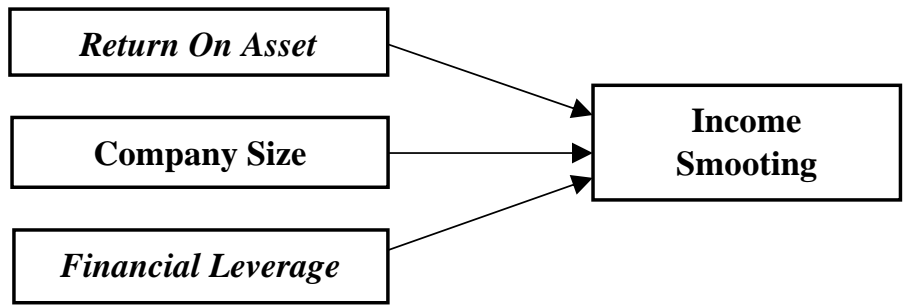

\section{Return On Asset (ROA) Relationship with Income Smoothing}

Changes in ROA indicate changes in management's ability to generate profits by utilizing assets used in operating activities. If the change is bigger, it shows the greater the fluctuation in management's ability to generate profits. This situation affects investors when predicting profit and also predicting risk in investment so that it has an impact on investor confidence in the company. Meanwhile, on the other hand, management is motivated to carry out income smoothing practices so that reported earnings do not 
THE EFFECT OF RETURN ON ASSETS, COMPANY SIZE AND FINANCIAL LEVERAGE ON SMOOTHING MEASURES (EMPIRICAL STUDY ON STATE-OWNED CONSTRUCTION COMPANIES LISTED IN THE JAKARTA ISLAMIC INDEX FOR THE 2015-2018 PERIOD)

fluctuate so as to increase investor confidence in companies that have invested capital. In addition, a management practices income smoothing so that investors who have already invested in the company will continue to the next period and also attract new investors.

H1: Return on assets has an effect on income smoothing.

\section{Hubungan Ukuran Perusahaan dengan Perataan Laba}

One of the reasons for involving company size as an estimate of the effect of income smoothing is because small companies (the number of assets) have a tendency to carry out income smoothing practices compared to companies with relatively high total assets. This is because large companies get more "attention" (from investors) than small companies. The bigger the company, the greater the attention paid by the public or investors to the company, so that the bigger the size of the company, the less chance for managers to take income smoothing actions.

H2: Firm size has no effect on income smoothing.

\section{Relationship between Financial Leverage and Income Smoothing}

Debt Level or better known as Financial Leverage reflects the extent to which the company's assets can overcome the debt owned by the company. Financial leverage can be detrimental to the company if the company cannot get income from the use of these funds in the amount of fixed expenses that are regularly paid. Companies with low financial leverage ratio analysis have a smaller risk of loss, but also have lower returns. If the company has an analysis of financial leverage ratios or high debt levels, but also has the opportunity to earn a higher profit, and Vice Versa.

H3: Financial leverage affects income smoothing action

\section{METHODOLOGY}

This study uses secondary data, considering that secondary data obtained from the JII website is in the form of annual financial reports from 2015 to 2018 as well as other supporting data from the official websites of the related companies. The data collected is the annual report data and financial reports from construction companies owned by BUMN which are registered in JII from 2015 to 2018.

The population is BUMN-owned construction companies whose shares are listed on the Jakarta Islamic Index from 2015 to 2018. Meanwhile, the sampling technique used is all BUMN-owned construction companies listed in JII. From the above characteristics, it is found that companies engaged in construction owned by BUMNs registered in JII from 2015 to 2018, there are 3 construction companies owned by BUMN, namely PT Waskita Karya (Persero) Tbk with the ticker code WSKT, PT Wijaya Karya (Persero) Tbk with the ticker code WIKA and PT Waskita Beton Precast Tbk with the ticker code WSBP. This study uses purposive sampling technique, with the criteria applied are:

1. State-owned construction company registered in JII 2015-2018.

2. BUMN-owned construction companies that are not BUMN subsidiaries. 


\section{AFEBI Islamic Finance and Economic Review (AIFER)}

\section{Vol.3 No.2, December 2018}

3. Companies that report audited annual financial statements for the 2015-2018 period.

4. Availability and completeness of audited 2015-2018 data.

Research Variables and Measurement Variables are presented in the table below :

Table 1. Variables and Measurement Variables

\begin{tabular}{|c|c|c|}
\hline Variable & Operational Definition & Measurement \\
\hline $\begin{array}{l}\text { Income } \\
\text { smoothing }\end{array}$ & $\begin{array}{l}\text { Income smoothing is an } \\
\text { action to minimize } \\
\text { fluctuations in earnings that } \\
\text { will be reported in each } \\
\text { period. } \\
\text { Measurement of income } \\
\text { smoothing uses the Eckel } \\
\text { Index (1981) using the Index } \\
\text { Coefficient Variation (CV) }\end{array}$ & $\begin{array}{l}\text { Income smoothing }=\frac{\mathrm{CV} \Delta \mathrm{I}}{\mathrm{CV} \Delta \mathrm{S}} \\
\text { where : } \\
\Delta \mathrm{I}: \text { Change in profit over a period of } \\
\text { time } \\
\Delta \mathrm{S}: \text { Change in operating income for a } \\
\text { period } \\
\mathrm{CV}: \text { The coefficient of variation of } \\
\text { the variable, namely : } \\
\text { Coefficient variation } \\
\qquad=\frac{\text { Standard deviation }}{\text { Expected value }} \\
\text { Thus, CV } \Delta \mathrm{I}=\text { coefficient of variation } \\
\text { for changes in earnings } \\
\mathrm{CV} \Delta \mathrm{S}=\text { coefficient of variation for } \\
\text { changes in income } \\
\mathrm{CV} \Delta \mathrm{I} \text { or } \mathrm{CV} \Delta \mathrm{S} \text { can be calculated as } \\
\text { follows: } \\
\mathrm{CV} \Delta \mathrm{I} \text { and } \mathrm{CV} \Delta \mathrm{S}=\frac{\sqrt{\Sigma(\Delta \mathrm{X}-\Delta \mathrm{X})}}{\mathrm{n}-1} \\
\text { If the Eckel Index value is } \geq 1, \text { then } \\
\text { the company does not do income } \\
\text { smoothing and is given the symbol } 0 . \\
\text { Whereas if the Eckel Index value is } \\
<1, \text { then the company practices } \\
\text { income smoothing and is given } \\
\text { symbol } 1 .\end{array}$ \\
\hline $\begin{array}{l}\text { Return On } \\
\text { Asset }\end{array}$ & $\begin{array}{l}\text { Return On Asset is a ratio } \\
\text { used to determine the ratio of } \\
\text { net profit after tax to total } \\
\text { company assets. }\end{array}$ & $\begin{array}{l}\text { Return On Asset (ROA) } \\
=\frac{\text { Earning After Tax x 100\% }}{\text { Total Assets }}\end{array}$ \\
\hline $\begin{array}{l}\text { Company } \\
\text { Size }\end{array}$ & $\begin{array}{l}\text { The size of the company or } \\
\text { firm size is the size or size of } \\
\text { the company which is } \\
\text { assessed in terms of total } \\
\text { assets }\end{array}$ & Company Size $=$ Total Assets \\
\hline $\begin{array}{l}\text { Financial } \\
\text { Leverage }\end{array}$ & $\begin{array}{l}\text { Use of funds with fixed } \\
\text { expenses. }\end{array}$ & $\begin{array}{l}\text { Debt to equity ratio } \\
\qquad=\frac{\text { Total liabilities }}{\text { Asset Capital }}\end{array}$ \\
\hline
\end{tabular}




\section{THE EFFECT OF RETURN ON ASSETS, COMPANY SIZE AND FINANCIAL LEVERAGE ON SMOOTHING MEASURES (EMPIRICAL STUDY ON STATE-OWNED CONSTRUCTION COMPANIES LISTED IN THE JAKARTA ISLAMIC INDEX FOR THE 2015-2018 PERIOD)}

The research data will be analyzed using the SPSS analysis tool to test the hypothesis.

\section{ANALYSIS}

\section{Descriptive statistics}

Table 2. Descriptive statistics

\begin{tabular}{|l|r|r|r|r|r|}
\hline & $\mathrm{N}$ & \multicolumn{1}{|c|}{ Min } & \multicolumn{1}{c|}{ Max } & \multicolumn{1}{c|}{ Mean } & Std. Deviation \\
\hline Return On asset & 12 & .03 & .11 & .0559 & .02264 \\
Company Size & 12 & 10.32 & 18.64 & 16.6378 & 2.20768 \\
Financial Leverage & 12 & .45 & 3.31 & 1.8672 & 1.06218 \\
Income Smoothing & 12 & -4.82 & 2.01 & -.3178 & 1.62733 \\
Valid N (listwise) & 12 & & & & \\
\hline
\end{tabular}

Source: processed data, 2019

The minimum value for the variable Return On Asset in BUMN-owned construction companies is 0.3 and the maximum value is 0.11 with an average value of 0.559. This means that the ratio of the smallest net profit after tax is 0.3 and the largest net profit ratio is 0.11 . The standard deviation of 0.0226 shows the variations contained in the Return On Assets of construction sector companies. From the data on return on assets or profitability, it can be seen that the average value is 0.559 with a standard deviation of 0.0226 , a standard deviation value that is smaller than the average indicates that the construction company being the sample is less varied or the sample lacks many values to be tested. The average value of return on assets of 0.559 is closer to the maximum, so that the average value of return on assets in this sample is quite high. Fixed assets in each sample company from year to year tend to increase. There are several factors that influence this, namely an increase in asset value, an increase in fixed assets which increases in value every year and so on.

The firm size variable has the smallest value of 10.32 and the largest value is 18.64 with an average value of 16.6378 . Thus the value of company size affects the CV $\Delta \mathrm{I}$ calculation which will also affect the income smoothing calculation. However, with an average value of 16.6378 this figure is not yet close to negative, so that the average company size value in the sample used is quite varied.

Variable Financial Leverage of the company, the greater the value of these variables, the greater the value of the ratio of debt to total assets. The smallest type of construction business was 0.45 and the largest value was 3.31 with an average value of 1.8672. This means that the sample companies have the least ratio between debt to total assets is 3.31. The standard deviation value for the Financial Leverage variable is 1.0621, which is greater than the mean value of 1.8672 . This result shows that the construction companies owned by the BUMNs sampled in this study have on average financial leverage or use sources of funds from investors to finance operational activities. The company has a mean result of 1.8672 which is greater than the mean firm size. This result 


\section{AFEBI Islamic Finance and Economic Review (AIFER)}

\section{Vol.3 No.2, December 2018}

is due to an increase in accounts payable experienced by each sample company. However, the increase in trade payables is directly proportional to the increase in construction work income.

Descriptive analysis test for the dependent variable, namely income smoothing, it can be seen that the standard deviation value is 1.627 and the mean value is -0 , the smallest is -4.82 , this means that most of the sample companies through the eckel index calculation do not perform income smoothing. The highest value of the income smoothing variable was 2.01, which means that from all data samples of construction companies owned by BUMN that were listed in JII, there was only 1 company in 1 period that carried out income control measures. Low income smoothing reflects the high level of honesty and transparency of management in the financial statements presented.

\section{Classic Assumption Test}

\section{Normality test}

The normality test is carried out to test whether the regression model is normally distributed or not. Normal distribution is detected using nonparametric statistical analysis Kolomogorov-Smirnov (K-S) with the decision rule if the significant value is more than alpha $=0.05$, it can be said that the data is normally distributed. Based on the SPSS output table, it is known that the significance value of Asymp.Sig (2-tailed) is 0.704>0.05. Based on the decision making in the Kolmogorov-Smirnov normality test in the table, it can be concluded that the data is normally distributed, meaning that the companies that are the sample are normally distributed.

Table 3. One-Sample Kolmogorov-Smirnov Test

\begin{tabular}{|c|c|c|}
\hline & Unstandardized Residual \\
\hline \multicolumn{2}{|l|}{$\mathrm{N}$} & 12 \\
\hline Normal & Mean & $0 \mathrm{E}-7$ \\
\hline Parameters ${ }^{\mathrm{a}, \mathrm{b}}$ & Std. & .76707224 \\
\hline & Deviation & ים \\
\hline Most Extreme & Absolute & , 203 \\
\hline Differences & Negative & $\begin{array}{r}, 144 \\
-203\end{array}$ \\
\hline Kolmogorov-S & nov Z &, 705 \\
\hline Asymp. Sig. (2 & iled) & ,704 \\
\hline
\end{tabular}

a. Test distribution is Normal.

b. Calculated from data.

\section{Multicollinearity Test}

The multicollinearity test was carried out using the VIF value. A variable shows multicollinearity symptoms seen from the VIF (Variance Inflation Factor) value greater than 10, then multicollinearity occurs. Following are the multicollinearity test results: 
THE EFFECT OF RETURN ON ASSETS, COMPANY SIZE AND FINANCIAL LEVERAGE ON SMOOTHING MEASURES (EMPIRICAL STUDY ON STATE-OWNED CONSTRUCTION COMPANIES LISTED IN THE JAKARTA ISLAMIC INDEX FOR THE 2015-2018 PERIOD)

Tabel 4. Coefficients ${ }^{\mathrm{a}}$

\begin{tabular}{|c|c|c|c|c|c|c|}
\hline \multirow{2}{*}{\multicolumn{2}{|c|}{ Model }} & \multicolumn{2}{|c|}{$\begin{array}{l}\text { Unstandardized } \\
\text { Coefficients }\end{array}$} & \multirow{2}{*}{$\begin{array}{c}\begin{array}{c}\text { Standardized } \\
\text { Coefficients }\end{array} \\
\text { Beta }\end{array}$} & \multicolumn{2}{|c|}{$\begin{array}{c}\text { Collinearity } \\
\text { Statistics }\end{array}$} \\
\hline & & B & Std. Error & & Tolerance & VIF \\
\hline \multirow[t]{4}{*}{1} & (Constant) & -.221 & 2.130 & & & \\
\hline & Return On asset & -17.731 & 12.825 & -.247 & .872 & 1.147 \\
\hline & Companiy Size & .145 & .128 & .196 & .918 & 1.089 \\
\hline & VAR_X3 & -.425 & .081 & -.965 & .824 & 1.213 \\
\hline
\end{tabular}

a. Dependent Variable: Perataan Laba

Based on the output table "Coefficients" in the "Collinearity Statistics" section, it is known that the VIF value for the variables Return On Asset (X1), Company Size (X2) and Financial Leverage (X3) <10. So it can be concluded that all independent variables are used in the research regression model. it is free from multicollinearity.

\section{Heteroscedasticity Test}

The Glejser test is a hypothesis test to determine whether a regression model has an indication of heteroscedasticity or not in the presence of an inequality of variants of the residuals for observations in the regression model.

Tabel 5. Coefficients ${ }^{\mathrm{a}}$

\begin{tabular}{|c|c|c|c|c|c|c|}
\hline \multirow{2}{*}{\multicolumn{2}{|c|}{ Model }} & \multicolumn{2}{|c|}{$\begin{array}{c}\text { Unstandardized } \\
\text { Coefficients }\end{array}$} & \multirow{2}{*}{$\begin{array}{c}\text { Standardized } \\
\text { Coefficients }\end{array}$} & \multirow[b]{2}{*}{$\mathrm{T}$} & \multirow[b]{2}{*}{ Sig. } \\
\hline & & $\mathrm{B}$ & Std. Error & & & \\
\hline 1 & (Constant) & .486 & .830 & & .586 & .574 \\
\hline & Return On asset & 5.508 & 4.995 & .318 & 1.103 & .302 \\
\hline & Company size & .001 & .050 & .005 & .018 & .986 \\
\hline & VAR_X3 & -.050 & .031 & -.470 & -1.585 & .152 \\
\hline
\end{tabular}

a. Dependent Variable: ABS_RES2

Heteroscedasticity test with Glejser test saw the output table "Coefficients" with the variable Abs_RES2 acting as a role as the dependent variable. Based on the output, it is known that the significance (Sig) for the variable Return on assets (X1), Company Size (X2) and Financial Leverage (X3) which has been transformed has a significance value greater than 0.05 , so according to the basis for decision making in the Glejser test, it can be concluded that there are no symptoms of heteroscedasticity.

\section{Autocorrelation Test $i$}

The autocorrelation test is carried out by using the Run Test, the results are as follows: 
Tabel 6. Runs Test

\begin{tabular}{|l|r|}
\hline & $\begin{array}{r}\text { Unstandardiz } \\
\text { ed Residual }\end{array}$ \\
\hline Test Value $^{\mathrm{a}}$ & .10877 \\
Cases < Test Value & 6 \\
Cases >= Test Value & 6 \\
Total Cases & 12 \\
Number of Runs & 8 \\
Z & .303 \\
Asymp. Sig. (2- & .762 \\
tailed)
\end{tabular}

a. Median

Based on the "Unstandardized Residual" output, the Asymp value is known. Sig. (2-tailed) is $0.762>0.05$, which means that the null hypothesis failed to be rejected. Thus, the data used is quite random or random so that there is no autocorrelation problem in the variables being tested.

\section{Hypothesis Testing}

Hypothesis testing is a process to test the significance of multiple linear regression coefficients partially related to the hypothesis statement used in the study.

Tabel 7. Coefficients ${ }^{\mathrm{a}}$

\begin{tabular}{|c|c|c|c|c|c|c|}
\hline \multirow{2}{*}{\multicolumn{2}{|c|}{ Model }} & \multicolumn{2}{|c|}{$\begin{array}{l}\text { Unstandardized } \\
\text { Coefficients }\end{array}$} & \multirow{2}{*}{\begin{tabular}{|c|}
$\begin{array}{c}\text { Standardized } \\
\text { Coefficients }\end{array}$ \\
Beta \\
\end{tabular}} & \multirow[b]{2}{*}{$\mathrm{t}$} & \multirow[b]{2}{*}{ Sig. } \\
\hline & & B & Std. Error & & & \\
\hline \multirow[t]{4}{*}{1} & (Constant) & -.221 & 2.130 & & -.104 & .920 \\
\hline & Return On asset & -17.731 & 12.825 & -.247 & -1.382 & .204 \\
\hline & Company size & .145 & .128 & .196 & 1.129 & .292 \\
\hline & VAR_X3 & -.425 & .081 & -.965 & -5.258 & .001 \\
\hline
\end{tabular}

a.Dependent Variable:Perataan Laba

The variable return on assets with income smoothing and company size has a value of Sig> 0.05, which means that there is no significant effect between Return on Assets and Company Size on Income Smoothing. Financial Leverage variable with test value $=0.001>0.05$, which means that Financial Leverage has a significant effect on income smoothing.

The results of the simultaneous significant test (f test) produce a sig. with a value of $0.005<0.05$, it can be concluded that there is an influence between Return On Assets (X1), Company Size (X2), and Financial Leverage (X3) on income smoothing action (Y). 
Tabel 8. Model Summary

\begin{tabular}{|c|c|c|c|c|c|c|c|c|c|}
\hline \multirow[b]{2}{*}{ Model } & \multirow[b]{2}{*}{$\mathrm{R}$} & \multirow[b]{2}{*}{$\begin{array}{c}\mathrm{R} \\
\text { Square }\end{array}$} & \multirow[b]{2}{*}{$\begin{array}{l}\text { Adjusted } \\
\text { R Square }\end{array}$} & \multirow{2}{*}{$\begin{array}{l}\text { Std. } \\
\text { Error of } \\
\text { the } \\
\text { Estimate }\end{array}$} & \multicolumn{5}{|c|}{ Change Statistics } \\
\hline & & & & & $\begin{array}{c}\mathrm{R} \\
\text { Square } \\
\text { Change }\end{array}$ & $\begin{array}{c}\text { F } \\
\text { Chang } \\
\text { e }\end{array}$ & df1 & df2 & $\begin{array}{c}\text { Sig. F } \\
\text { Change }\end{array}$ \\
\hline 1 & $.882^{\mathrm{a}}$ & .778 & .694 & .89947 & .778 & 9.335 & 3 & 8 & .005 \\
\hline
\end{tabular}

a. Predictors: (Constant), VAR_X3, Ukuran

Perusahaan, Return On asset

Based on the Model Summary table, it is known that the magnitude of the influence of Return On Assets, Company Size and Financial Leverage (simultaneously) on the performance calculated by the correlation coefficient is 0.778 , this indicates a moderate effect. Meanwhile, the simultaneous contribution or contribution of the variable Return on Assets, Company Size and Financial Leverage to income smoothing is $77.8 \%$ while $22.2 \%$ is determined by other variables. The probability value (sig F Change) = $0.005<0.05$, the decision is that simultaneously Return On Assets, Company Size and Financial Leverage have a significant effect on income smoothing actions in BUMNowned construction companies listed in JII from 2015 to 2018.

The Standard Error of the Estimate value results in a value of 0.8994 , this indicates a value that is not too large so that it can be concluded that the regression model is suitable to be used to predict the dependent variable. Meanwhile, the $\mathrm{R}$ value of 0.882 shows that the relationship between the dependent variable and the independent variable (ROA, company size and financial leverage) is quite strong.

\section{RESULTS}

\section{Income Smoothing}

Referring to the results of this study's calculation, it shows that the majority of state-owned construction companies are classified as non-grading. There is only 1 company in 1 period that is classified as a leveler, namely PT Waskita Beton Precast (Persero) Tbk in 2017. From these results, the calculation of income smoothing, that later the red plate construction company will spearhead the development of a new capital free from income smoothing, so that the government will be able to make correct and accurate decisions regarding everything related to development expenditures. Based on the results of the eckel index test using categorized samples, in this study most companies did not perform income smoothing. However, there are other variables that can prove that the sample does income smoothing through the variables used in this study.

\section{Return On Asset (ROA)}

Return On Asset is a ratio used to determine the ratio of net profit after tax to the total assets of the company. The ROA value shows the company's ability to generate profits based on the assets owned by each company. 


\section{AFEBI Islamic Finance and Economic Review (AIFER)}

\section{Vol.3 No.2, December 2018}

Based on the results of the analysis carried out on 3 construction companies owned by BUMN, the Jakarta Islamic Index for the 2015-2018 period obtained results that describe the level of income smoothing. The smoothing index value of the smallest construction company is - 0.482936 which is obtained from the comparison of the coefficient of variation $(\mathrm{CV})$ of change in earnings $(\Delta \mathrm{I})$ and the coefficient of variation (CV) of change in sales in one period owned by PT Wijaya Karya (Persero) Tbk. Meanwhile, the largest smoothing index is 0.556366 at PT Waskita Karya (Persero) Tbk.

The results of descriptive statistics in this study show that the average construction company owned by BUMN has the value of Sig. $0.204>0.05$ then there is no effect of the ROA variable on income smoothing. This indicates that the income smoothing action for construction companies owned by BUMN is low. This is probably due to the assumption that income smoothing is an act of fraud that is prohibited and must be prevented. However, in this study using an object on Sharia stocks, specifically the Jakarta Islamic Index, where if the company is going to enter or list the Sharia securities, of course, it has met the predetermined requirements. MUI DSN Fatwa No. 87 / DSNMUI / XII / 2012 has considered if the company is allowed to save or reserve profits with the intention of guarding against possible unfavorable conditions in the next period so that it can make a company's profit decline and also the company's operational continuity. In addition, this can also indicate that management is less able to reduce the fluctuations in reported earnings. The best of all things considered, this article was originally published in Indonesian language.

The results of this study are contrary to the hypotheses that have been formulated, but are in line with the results of research conducted by Shanie Sukmawati, Kuasmuriyanto and Linda Agustina (2014) which result that return on assets has no effect on income smoothing.

\section{Company Size}

In the $t$ test it is known that company size has an effect of $0.292>0.05$, so there is no effect on income smoothing action. This result is in line with the hypothesis stated in the previous chapter if $\mathrm{H} 2$ : firm size has no significant effect on income smoothing. The results of this study, which means that the bigger the company, the less chance the company manager will practice income smoothing. The insignificance of the size of the company in this study is probably due to the fact that company managers in terms of income smoothing practices have different personal interests regardless of whether the company is large or small, which means that large and small companies have the opportunity to carry out income smoothing practices depending on the personal manager of each company. In addition, company size has no effect on income smoothing because the income smoothing carried out by the sample companies is not triggered by the size of the sample companies, but on the basis of the company's goal of wanting a larger investment. During this research, the company had high assets because there was also an increase in projects in line with the central government's work program, namely infrastructure development to support the Indonesian economy.

This result is the same as the research conducted by Shanie Sukmawati, Kuasmuriyanto and Linda Agustina (2014) which results that company size has no effect on income smoothing. In addition, research conducted by Harris Prasetya and Shiddiq Nur Rahardjo (2013) also shows that there is no effect. 


\section{THE EFFECT OF RETURN ON ASSETS, COMPANY SIZE AND FINANCIAL LEVERAGE ON SMOOTHING MEASURES (EMPIRICAL STUDY ON STATE-OWNED CONSTRUCTION COMPANIES LISTED IN THE JAKARTA ISLAMIC INDEX FOR THE 2015-2018 PERIOD)}

\section{Financial Leverage}

Financial Leverage is measured by using total debt (liabilities) divided by total capital (equity) to produce a debt to equity ratio (DER). In calculating the DER, the composition of debt and equity is shown. The debt every year at each company tends to increase every year. This is the impact of routine activities of construction sector companies, namely other trade payables and equipment lease payables. In addition, there was also an increase in short-term bank debt by third parties.

Based on the test results of the influence of the Financial Leverage variable using the DER calculation on earnings after transforming the variable using the variance, it is known that the $t$ test for the Financial Leverage variable has a Sig value. $0.001<0.05$, then there is an effect of the variable Financial Leverage on income smoothing. This result is in accordance with the hypothesis that "financial leverage affects income smoothing action" is accepted. This is consistent with research conducted by Sartono (2001) in Diastiti (2010) that financial leverage shows the portion of debt use to finance investment. In addition, research conducted by Siti, Muslih and Wiwin (2019) also stated that DER has an influence on income smoothing. In addition, there is research from Nur Fitri, Eyo Astro Sasmita and Amir Hamzah (2018) which also shows that Financial Leverage has an effect on income smoothing. The results showed that the financial leverage variable has an effect on income smoothing action, this means that if the company's debt is high, the company's risk is also high. Companies that have a high risk can make investors get more dividends from the investment they have given to the company. This can make managers practice income smoothing, so that the resulting profit looks stable (profit fluctuations are not too high or too low between periods). If the manager records a stable profit, investors will assume that the company is able to reduce risk.

\section{CONCLUSION}

1. Generate analysis showing that Return On Asset has no significant effect on income smoothing actions in BUMN-owned construction companies listed in JII 2015-2018. This indicates that management is less able to reduce reported fluctuations in earnings, because within a certain period of time it is likely that a company will experience fluctuations in earnings.

2. The results of the analysis show that company size has no effect on income smoothing actions in state-owned construction companies listed in JII 20152018. This proves that big or small a company has the opportunity to take income smoothing action depending on the personal manager of each company.

3. The results of the analysis show that financial leverage has an effect on income smoothing action in state-owned construction companies listed in JII 20152018. From these results it can be concluded that the higher the level of financial leverage of the company, the company chooses to practice income smoothing.

\section{Limitations}

This study has limitations, namely: 


\section{AFEBI Islamic Finance and Economic Review (AIFER)}

\section{Vol.3 No.2, December 2018}

1. Using the Eckel Index (1981) which may have an insignificant effect on research conclusions.

2. The number of research objects only focuses on 3 companies for 4 periods so that the sample that can be used is 12 .

3. Only use three variables of return on assets, company size and financial leverage

\section{Suggestion}

1. Future research, if you want to use state-owned companies, can combine it with private companies with similar fields so that a larger number of samples can be obtained.

2. Research that focuses on income smoothing should use an index or other calculation similar to the Eckel Index (1981).

3. For research that will test income smoothing as the "Y" variable, it is necessary to use other variables or add variables, such as type of business, net profit margin (NPM), ownership structure or other variables.

\section{Reference}

ari Kristin Prasetyoningrum, "Pengaruh Ukuran Perusahaan, Leverage , Efisiensi Biaya, Dan Umur Perusahaan Terhadap Islamic Social Reporting ( Isr ) Pada Perbankan Syariah Di Indonesia” 2, no. 2 (2018): 147-62.

Budi Santoso, Eko., Sherly Novia Salim (2012). "Pengaruh Profitabilitas, Financial Leverage, Dividen, Ukuran Perusahaan, Kepemilikan institusional dan kelompok usaha Terhadap Perataan Laba: Studi Khasus pada Perusahaan Non-Finansial Yang Terdaftar di BEI." Jurnal Akuntansi dan Bisnis Vol 1, No. 1. Universitas Islam Sultan Agung

Budiasih, I.G.A.N. 2009. "Faktor-faktor Yang Mempengaruhi Praktik Perataan Laba." AUDI Jurnal Akuntansi \& Bisnis, 4(1)

Diastiti Okkarisma Dewi, "Skripsi :Pengaruh Jenis Usaha, Ukuran Perusahaan Dan Financial Leverage Terhadap Tindakan Perataan Laba Pada perusahaan Yang Terdaftar Di Bursa Efek Indonesia" Universitas Diponegoro, 2010,

Dinarjito, A. (n.d.). TERDAFTAR DI BURSA EFEK INDONESIA SEBAGAI AKIBAT, 2, 1-18.

Ekonomika, F., Bisnis, D. A. N., \& Diponegoro, U. (2013). ANALISIS PENGARUH NPM , ROA , UKURAN PERUSAHAAN DAN FINANCIAL LEVERAGE TERHADAP PRAKTIK PERATAAN LABA ( Studi Kasus pada Perusahaan Manufaktur yang Terdaftar di BEI Tahun 2008-2011 ).

Eva Rosa Dewi Sutino and Moh Khoiruddin, "Pengaruh Good Corporate Governance Terhadap Manajemen Laba Pada Perusahaan Yang Masuk Dalam JII (Jakarta Islamic Index) Tahun 2012-2013," Management Analysis Journal 5, no. 3 (2016): 156-66. 


\section{THE EFFECT OF RETURN ON ASSETS, COMPANY SIZE AND FINANCIAL LEVERAGE ON SMOOTHING MEASURES (EMPIRICAL STUDY ON STATE-OWNED CONSTRUCTION COMPANIES LISTED IN THE JAKARTA ISLAMIC INDEX FOR THE 2015-2018 PERIOD)}

Framita, D. S. (2018). PENGARUH RETURN ON ASSET (ROA), NET PROFIT MARGIN (NPM), DEBT TO EQIUTY RATIO (DER), LEVERAGE OPERASI, DAN UKURAN PERUSAHAAN TERHADAP PRAKTIK PERATAAN LABA PADA PERUSAHAAN MANUFAKTUR SEKTOR INDUSTRI DASAR DAN KIMIA YANG TERDAFTAR DI BEI. Jurnal Akuntansi : Kajian Ilmiah Akuntansi (JAK).

https://ekbis.sindonews.com/read/1292694/32/laba-meningkat-tiga-bumn konstruksibuktikan kinerja-positif 1522038991

https://www.idx.co.id/idx-syariah/indeks-saham-syariah/ dilansir 18 Februari pukul 00.20

https://www.kemenkeu.go.id/apbn2018

https://doi.org/10.30656/jak.v5i2.667

https://www.waskita.co.id/pages/about/company-profile?lang=id diakses pada

Februari 10.04

Fatwa Dewan Syariah Nasional, Metode Perataan Penghasilan (Income Smoothing)

Dana Pihak Ketiga, (NO: 87/DSN-MUI/XII/2012), hal 6

Januar Eko dan Bambang Suryono. 2007. "Pengaruh Perataan Laba terhadap Respon Pasar dengan Kualitas $\quad$ Auditor sebagai Variabel Pemoderasipada Pemoderasi pada Pe

Kumaladewi, P. R. 2008. "Pengaruh Perubahan Return On Assets, Perubahan Operating Profit Margin, Dan Ukuran Perusahaan Terhadap Kemungkinan Praktik Perataan Laba Pada Perusahaan Manufaktur Yang Terdaftar Di Bursa Efek Indonesia”. Universitas Atmajaya.

Kurniawan, M.S., Sri Wahjuni Latifah., Siti Zubaidah. 2012. "Pengaruh ROA, Ukuran Perusahaan dan Financial Leverage Terhadap Tindakan Perataan Laba." Jurnal Akuntansi dan Investasi, Vol 13 (2), hal 69.

Lamy, P., Floyd, O., Quémerais, E., Boclet, B., \& Ferron, S. (2017). Coronal massejections and solar wind mass fluxes over the heliosphere during solar cycles 23 and 24 (1996-2014). Journal of Geophysical Research: Space Physics, 122(1), 50-62. https://doi.org/10.1002/2016JA022970

Lisusanti Kharecha Siti, Muhammad muslih., Wiwin Aminah. 2019. "pengaruh Profitabilitas, UKuran Perusahaan dan Risiko Keuangan terhadap PerataanLaba Studi Kasus pada Perusahaan sector Properti, Real Estate dan Konstruksi Bangunan yang terdaftar di BEI 2013-2017." e-Proceeding of Management : Vol.6, No.2, hal 3552

M.S Kurniawan, Sri Wahjuni Latifah, Siti Zubaidah. 2012. Pengaruh Return On Asset, Ukuran Perusahaan Dan Financial Leverage Terhadap Tindakan Perataan Laba Studi Empiris Pada Perusahaan Sektor Keuangan Yang Terdaftar di BEI. Universitas Muhammadiyah Malang. 


\section{AFEBI Islamic Finance and Economic Review (AIFER)}

\section{Vol.3 No.2, December 2018}

Muhammad Noor Ardiansah dan Etna Nur Afri Yuyetta. "Dampak Kinerja Investasi, Risiko Keuangan, Nilai Perusahaan dan perataan Laba Terhadap Tingkat Profitabilitas Industri Konstruksi”. Jurnal Riset dan Akuntansi dan Manajemen, 4(1), September 2019, 106-114

Aplikasi :

Perusahaan, P. U., \& Prasetyoningrum, A. K. (2018). LEVERAGE , EFISIENSI BIAYA , DAN UMUR PERUSAHAAN TERHADAP ISLAMIC SOCIAL REPORTING ( ISR ) PADA PERBANKAN SYARIAH DI INDONESIA, 2(2), 147-162.

Prasetya Harris, Shiddiq Nur Rahardjo. 2013. "pengaruh ukuran Perusahaan, Profitabilitas, Financial Leverage, Klasifikasi KAP dan Likuiditas terhadap Praktik Perataan Laba.” Diponegoro Journal Of Accounting Volume 2, Nomor 4, Tahun 2013, Halaman 1-7 ISSN (Online) 23373806

Profit, N. E. T., Npm, M., Praktik, T., \& Laba, P. (1998). Bunga Maharani Program Studi Akuntansi Fakultas Ekonomi Universitas Jember, 75-89.

Suwandi. Etika Perataan Laba dari Perspektif Akuntansi Syariah. Akuntabilitas: Jurnal Ilmu Akuntansi Volume 10 (1), April 2017 P-ISSN: 1979 858X; E-ISSN: 2461-1190 Page 63 - 78

Suwito, Edy dan Arleen. 2005. "Analisis Pengaruh Karakteristik Perusahaan Terhadap Tindakan Perataan Laba yang Dilakukan oleh PerusahaanYang

Terdaftar di Bursa Efek Jakarta". Simposium Nasional Akuntansi VIII. Solo.

Sutino, Ed. R. D., \& Khoiruddin, M. (2016). Pengaruh Good Corporate Governance terhadap Manajemen Laba pada Perusahaan yang Masuk dalam JII (Jakarta Islamic Index) Tahun 2012-2013. Management Analysis Journal, 5(3), 156-166.

Tatang Ary Gumanti, Moeljadi dan Elok Sri Utami, Metode Penelitian Keuangan, Jakarta : Mitra Wacana Media, 2018, hlm. 185.

Wirakusuma, Made, and Ida Gayatri. "FAKTOR-FAKTOR YANG MEMPENGARUHI PERATAAN LABA PERUSAHAAN MANUFAKTUR YANG TERDAFTAR DI BURSA EFEK INDONESIA.” E-Jurnal Akuntansi, 2013.

Volume, J. (2018). Isue 2 , Agustus 2018: 1 - 14, 4, 1-14.

Widayanti, C. A., Vestari, M., \& Farida, D. N. (n.d.). Faktor-faktor yang mempengaruhi kualitas laba pada perusahaan high profile yang terdaftar di be.

Wirakusuma, M., \& Gayatri, I. (2013). FAKTOR-FAKTOR YANG MEMPENGARUHI PERATAAN LABA PERUSAHAAN MANUFAKTUR YANG TERDAFTAR DI BURSA EFEK INDONESIA. E-Jurnal Akuntansi. 